\title{
Grasses and Legumes at the Banana Field in the Panabo City, Philippines
}

\author{
Jovany Gleen L. Allawan \\ UM-Panabo College, Philippines
}

\begin{abstract}
Grasses and legumes play a major role in improving farm productivity in agriculture. The study determined the species of grasses and legumes at the banana field in the Panabo City, Philippines. A field layout was used as a guide in tagging the banana plants, which would correspond to a particular area in the field. These quadrats became the sampling plots of the study. The data collection was conducted in every randomly selected quadrat. Grasses and legume species enclosed in the quadrat were counted and descriptively characterized using a key identification guide on the basis of their morphological characteristics and with final confirmation from an expert. Data on species frequency, species diversity, and population density was also determined and analyzed total nitrogen and moisture content. The results showed four species of grasses (Chloris barbata, Echinochloa colona, Eleusine indica, and Rottboellia cochinchinensis) and two species of legumes (Mimosa pudica and Mimosa diplotricha). Based on the abundance and mean densities of grasses in the banana field, $R$. cochinchinensis dominated the study area, while the most abundant legume species was $M$. pudica. Soil analysis was found strongly acidic and there was a deficient of potassium, very low of phosphorus, and less organic matter. In addition, $M$. pudica had the highest nitrogen content of 3.14 while $M$. diplotricha had the highest moisture content of 82.6 among the identified species.
\end{abstract}

Keywords: grasses; legumes; banana field; tissue moisture and nitrogen content; Panabo City

\section{BACKGROUND OF THE STUDY}

$\mathrm{G}$ rasses and legumes are typically defined as crops used to protect agricultural soils and improve soil productivity. They are generally non-cash crops and rarely harvested. They may be used as green manure crop incorporated into the soil to increase soil organic matter and stimulate soil biological activity or improve soil physical characteristics. Grasses and legumes are also used to protect the soil from wind and water erosion (Entsminger, 2014). The use of cover crops in wellplanned crop rotations can help interrupt the life cycle of many fungal, bacterial, insect, or nematode pests (Walter et al., 2012). To interrupt pest life cycles, it is important to select cover crops of a different family than that of the future cash crop so that they do not harbor pests that can negatively impact the cash crop that will follow (Moines, 2018). It may also attract beneficial organisms that prey upon or parasitize pests. Some cultivars of brassica crops or mustards and pearl millet have been reported to suppress harmful nematode populations. Cover crops can contribute to pest management and reduce the use of pesticides (Ussery, 2011).

The Philippines contains 1.5 million hectares of grassland that is open to the public. Grazing is available to eligible groups and is managed by the government through Pasture Lease Agreements (PLA) and Forest Land Grazing Lease Agreements (FLGLA), which are handled by the Department of Environment and Natural Resources (DENR). The provinces of South Cotabato, North Cotabato, and Bukidnon in Mindanao; the island provinces of Masbate and Occidental Mindoro; and the provinces of Cagayan and Isabela in Luzon all have extensive grasslands (Moog, 2016). The local name for Imperata cylindrica, known as "cogon grass," dominates the Philippine grasslands, accounting for nearly half of the total grazing area. Themeda, Capillipedium, and Chryosopogon are three other significant grass community types found (Arora, 2014).

Grasse that grows in farmed rice and maize fields, such as Echinochloa colona, Rottboellia, Ischaemum rugosum, and Dactyloctenium aegyptium, serve as forages on small farms, the majority of which are designated weeds. Imperata cylindrica, Paspalum conjugatum, and Cyrtococcum spp. are other grass species utilized as feeds, and they grow naturally in orchards, wastelands, and idle lots, where most broadleaf species, such as Synedrella nodiflora, Pseudo-elephantopus spicatus, and Asystasia gangetica, may also be found. In cultivated areas, other broadleaf species thrive. Aside from weeds connected with cultivated crops, residues or farm byproducts from crop production provide the majority of the feed resources for ruminant production. Rice straw, maize stover, mungbean hay, sweet potato vines, cassava leaves, peanut hay, sugarcane tops, and pineapple pulp are just a few examples. Except for the latter, the majority of these resources are left on the field after harvest and burned. This is especially true of rice straw and sugarcane tops, and as a result, many crop leftovers are underutilized, if not completely discarded (Moog, 2016).

Panabo City is known as the banana capital of the Philippines due to numerous banana plantations scattered throughout the city. In fact, Panabo is the home of the world's biggest banana plantation, owned by the Tagum Agricultural Development Company (TADECO), which covers approximately 6,900 ha of banana fields and produces millions of boxes of export-quality bananas annually. The city itself cultivated $40 \%$ of its land or approximately 10,000 ha into planting export-quality bananas, which is better known as Cavendish bananas. Thus, banana cultivation and exportation are the main economic livelihood of the city. Barangay Kauswagan, Panabo City, Davao del Norte is a small community with an undeveloped land area. The area is 
grassland inhabited mainly by cogon grass (Cylindrica imperata) which is prone to recurrent grass fires (Pototan et al., 2017).

Banana field is not exempted from the possible occurrence of grasses. These grasses may have properties that can suppress some diseases of banana, such as the Fusarium wilt and Moko disease. Numerous pests and diseases cause serious damage in certain banana varieties as the Fusarium wilt where its spread is a major concern to sustainable production (Cartmill, 2021). This study focused on the grasses and legumes species present in the sampling site.

\section{Objectives of the Study}

The study assessed the current status of grass and legume species at the Banana Field of Panabo City, Davao del Norte. Specifically, it aimed to:

a. morphologically characterizes and identify grass and legume species inhabiting the sampling site;

b. determines species frequency, relative frequency, species density, and relative density of grasses and legumes;

c. determines species diversity and population density using Shannon-Weiner Diversity Index; and

d. determines the grass and legume tissue moisture and nitrogen content in the sampling site.

\section{METHOD}

Materials Used. The materials that were used in this study were map of the study site, Global Positioning System (GPS), ropes, and flaglets to obtain the coordinates in order to plot the quadrats. In getting the physico-chemical parameters of the site, the materials that were utilized were the tong or soil cork borer, thermometers, psychrometers, distilled water, weighing balance, beaker, and $\mathrm{pH}$ meter. In documentation, a digital camera, a record book, pen, and field guide were used.

Location of the Study. The study was conducted in the banana plantation of Gillera Farm, Barangay Kauswagan, Panabo City, Davao del Norte (Figure 1). The study site has a total land area of 30,000 sq. m. with the coordinates of $7^{\circ} 18^{\prime} 31.35^{\prime}, \mathrm{N}$ and $125^{\circ} 41^{\prime} 02.83^{\prime}$ ' E. Four blocks were established in the sampling area. Block 1 had a length of 37.9 $\mathrm{m}$ and a width of $52.9 \mathrm{~m}$; block 2 had a length of $37.9 \mathrm{~m}$ and a width of $11.01 \mathrm{~m}$; block 3 had a length of $37.9 \mathrm{~m}$ and a width of $23.7 \mathrm{~m}$; and block 4 had a length of $37.9 \mathrm{~m}$ and a width of $14.14 \mathrm{~m}$.

Establishment of Quadrats. A field layout was used as a guide in tagging the banana plants, which would correspond to a particular area in the field. Quadrats were randomly chosen using the calculator. These quadrats became the sampling plots of the study. The data collection was conducted in every randomly selected quadrat. From 1,000 banana plants, 100 quadrats were made all over the 1 ha banana field, measuring $1.5 \mathrm{~m} \times 2 \mathrm{~m}$ laid randomly in the study area. Based on the calculation, there were 17 quadrats placed on the first block, second block had 40 quadrats, 27 quadrats were on the third block, and the fourth block had 15 quadrats.

Sampling and Data Collection. Grass and legume samples were collected from the randomly selected quadrats. Grass and legume species enclosed in the quadrat were counted and descriptively characterized using a key identification guide on the basis of their morphological characteristics such as leaf arrangement, leaf incision, leaf shape, leaf venation, leaf margin, leaf apex, leaf base, ligule morphology, leaf auricle configuration, leaf sheath, type of inflorescence, inflorescence arrangement, stem shape, stem surface, stem modification and type of root (Figure 2)

Soil Analysis. Soil samples were taken from the sampling units and were classified into its type (sandy, clay, or loamy). Using a spade, soil sample at a depth of $30 \mathrm{~cm}$ to $50 \mathrm{~cm}$ from the surface were taken. Soil of the same type and topography were mixed. After soil collection, it was air dried indoor by spreading them in a clean wide sheet of cellophane. When dried, the representative soil samples were divided into four. Parts 1 and 3 were removed and parts 2 and 4 were retained. Parts 2 and 4 were mixed again and $1 \mathrm{~kg}$ from the mixture were taken and sealed in a clean plastic bag. The plastic bags were labeled and sent to the Bureau of Soils Laboratory for soil analysis.

Nitrogen and Moisture Contents of Plant Tissues. To determine the nitrogen content of plant tissues, Kjeldahl method was used. It was done by chopping the grass samples with a length of $2.54 \mathrm{~cm}$ before being sent to a laboratory for accurate purposes. For the moisture content, the samples were weighed before and after they were dried through oven for 1 hour (Jarchow and Liebman, 2013).

Statistical Analysis. Species frequency, relative frequency, species density, relative density and species diversity comprise the statistical analysis. Species frequency determines the number of times in which species occurs in a given number of quadrats sampled. It is defined as number of occurrences over the number of the sampled quadrats (Mashaly et al., 2020).

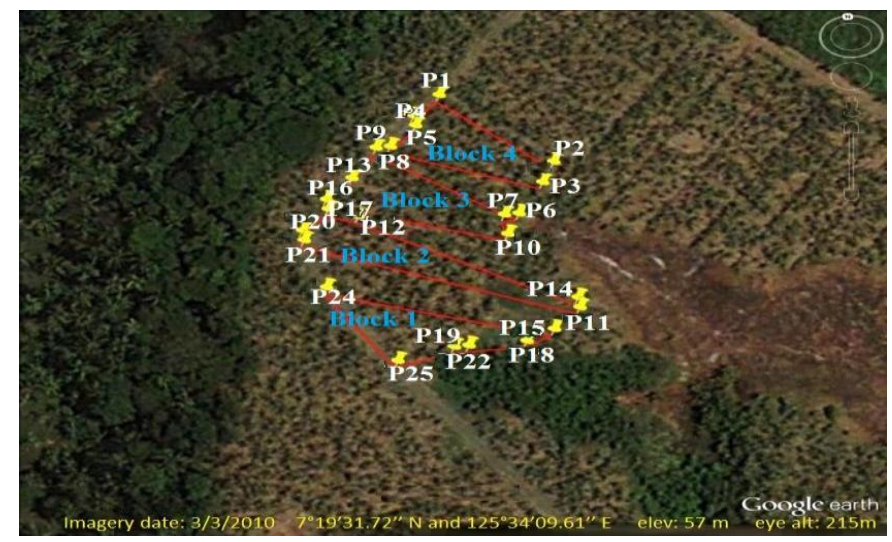

Figure 1. Establishment of the four blocks in the sampling area (Adapted from Google Earth 2014) 

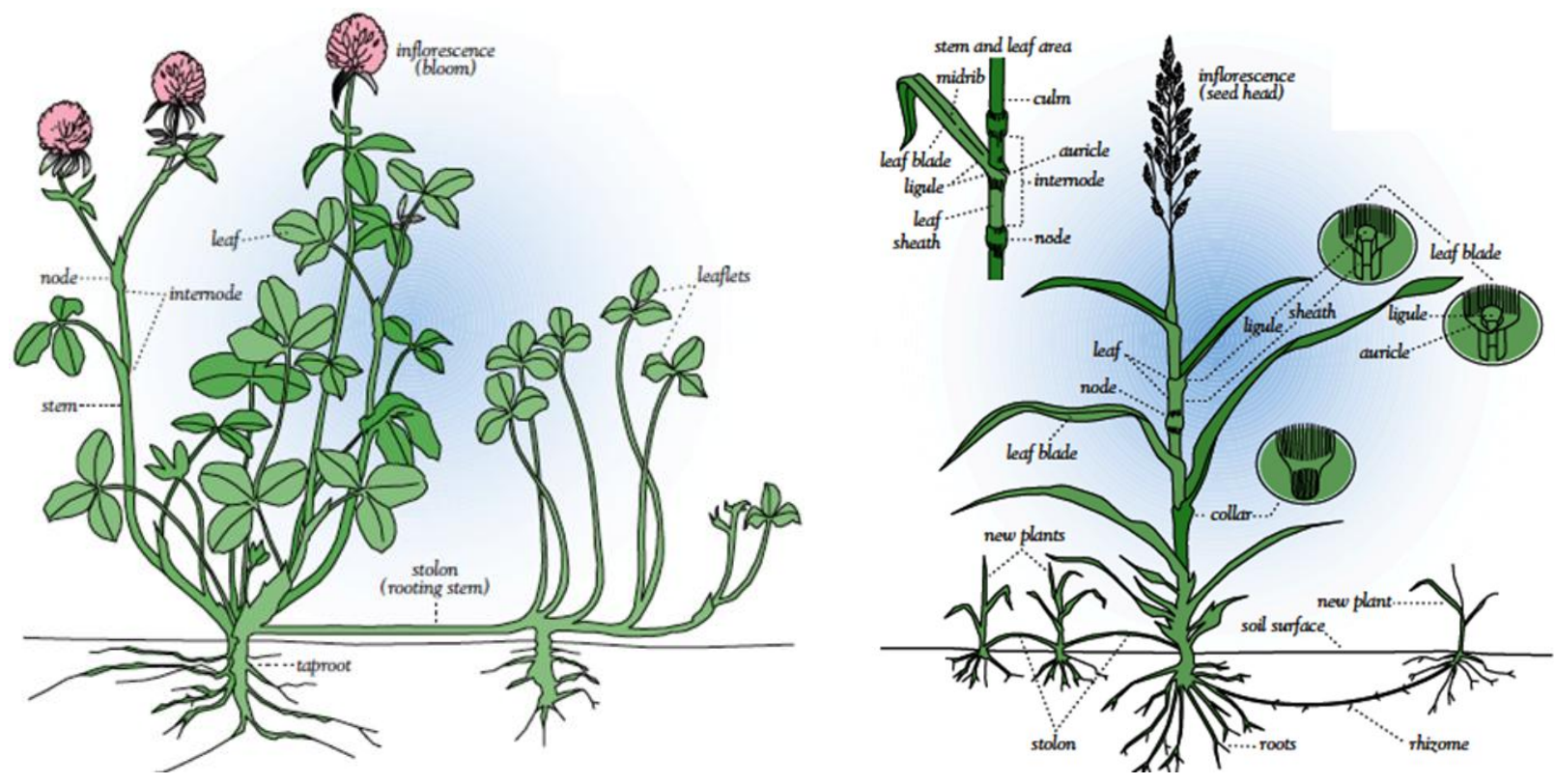

Figure 2. Grass and legumes morphology (Adapted from Henning et al. 2010)

\section{RESULTS AND DISCUSSION}

There were 4,604 individuals collected from the four blocks established within the banana field. There were four species of grasses and two species of legumes. The grasses were identified under the family Poaceae, namely: Chloris barbata, Echinochloa colona, Eleusine indica, and Rottboellia cochinchinensis. Based on the results, $R$. cochinchinensis was the most abundant grass in the area, while E. colona was the least abundant. For legumes, there were two identified species. These were Mimosa pudica with 297 individuals and Mimosa diplotricha with 257 individuals.

\section{Species Accounts}

\section{Chloris barbata (Chen, 2004)}

Chloris barbata (Figure 3) shows the actual view of the whole plant, leaves, inflorescence, stem, and roots of $C$. barbata. This grass species is commonly known as swollen finger grass. It is the second less abundant grass species in the study area and generally measured $70 \mathrm{~cm}$ with alternate leaf arrangement. The leaf incision was simple. The leaf shape had linear and parallel venation and its margin was scabrous. The leaf apex was acuminate while the leaf base was cuneate. Inflorescence of swollen finger grass was observed as had a raceme type of inflorescence and its racemes were erect, ascending, and straight. The spikelet was slightly laterally compressed with three florets. For stem morphology, the shape was observed as flat while the surface of the stem was smooth. The stem modification was tiller and the type of root was fibrous. Swollen finger grass is widely distributed throughout the subtropical and tropical regions on loams and limestone derived soil. It is widespread invasive species in the banana field. Thus, it is adapted to the environment in which it exists. It is a weedy species, often growing in waste areas, but also in cultivated fields (Reddy, 2011). This widespread species was also found in a banana plantation in Barangay Lacson, Calinan, Davao City, Philippines.

\section{Echinochloa colona (Monsanto, 2012)}

Echinochloa colona. This grass species belongs to the family Poaceae and were commonly referred to as the jungle rice grass. Figure 4 shows the whole plant, leaves, inflorescence, stem, and roots of E. colona. The whole plant measured from 30 to $34 \mathrm{~cm}$. For the leaf morphology of jungle rice grass, its leaf arrangement was alternate while the leaf incision was simple. The leaf shape was observed as linear to lanceolate and its leaf margin was entire. The leaf apex was acuminate and the leaf base was cuneate. Leaf surface was pubescent and its venation was parallel. The ligule morphology was absent. Its leaf auricle configuration was clasping and the leaf sheath was split. E. colona had a raceme type of inflorescence. The number of spikes was 11 and the arrangement was alternate. The height of the inflorescence was $7 \mathrm{~cm}$. For its stem morphology, the shape was flat. The surface of the stem was smooth. The stem modification was rhizomatous and the root was fibrous. The root measured $6 \mathrm{~cm}$. Jungle rice grass normally occurs in summer-irrigated crop fields, orchards, vineyards, around ponds and irrigation ditch banks, pastures and landscaped areas or other distributed moist areas. It was found throughout the Philippines, in most islands and provinces growing in open shallow water and in low, wet places, swamps, and borders of lakes and streams, at low and medium altitudes (Monsanto, 2012). It is the least abundant grass species in the study area.

This species was found in banana plantation in Barangay Lacson, Calinan, Davao City, Philippines and also 
in Barangay New Visayas, Panabo City. Jungle rice grass can tolerate moderate shading. It was a very competitive grass that can reproduce and compete effectively due to its prostate habit
(Monsanto, 2012). This grass species is not suitable to become cover crops because none of this species satisfy the given four criteria.
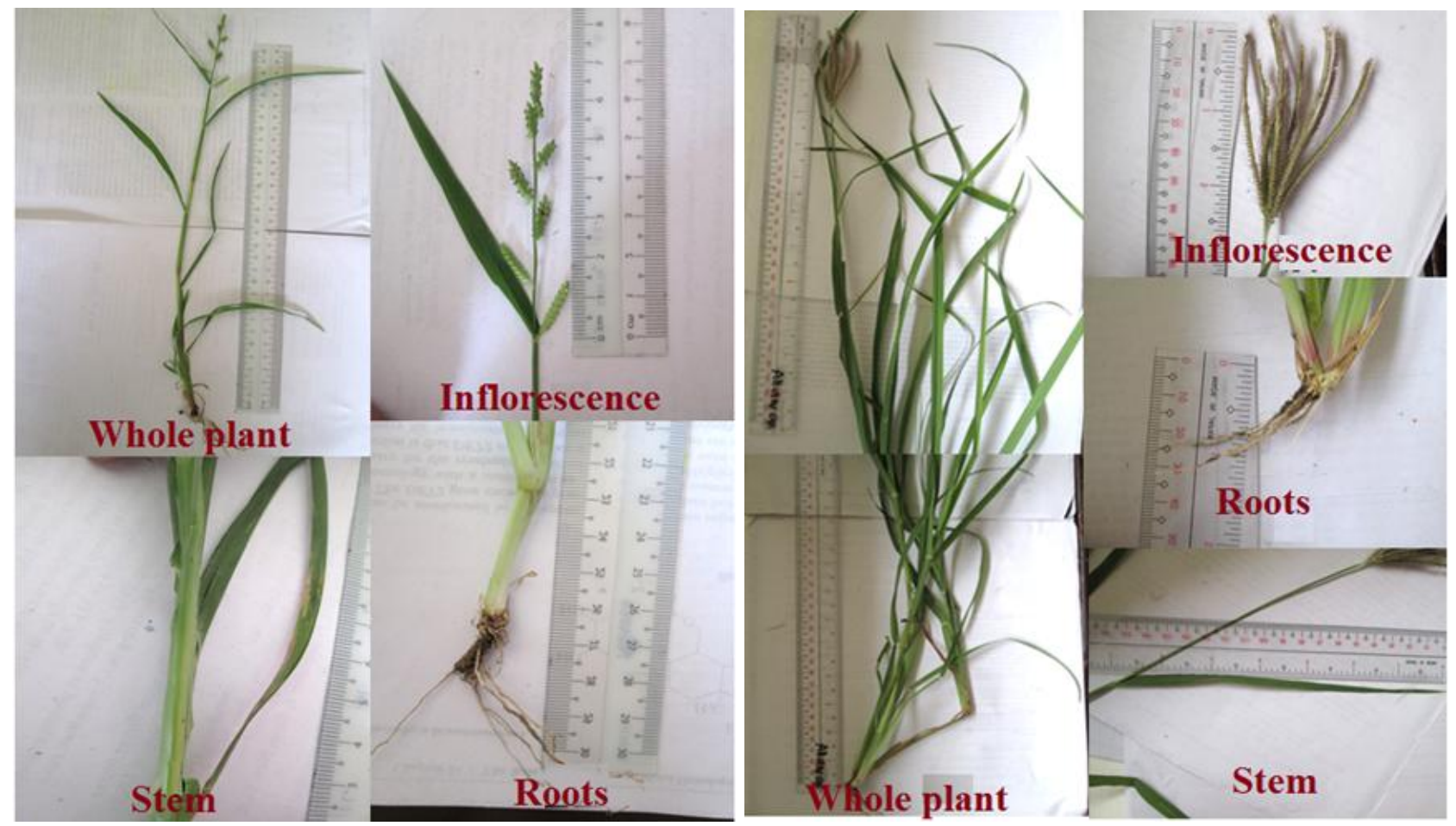

Figure 3. Chloris barbata

\section{Eleusine indica (Breeden \& Brosnan, 2009)}

Eleusine indica. It is commonly referred to as goose grass. This species belongs to the grass family Poaceae. Figure 5 shows the actual view of goose grass. The whole plant measured about $40 \mathrm{~cm}$ with alternate leaf arrangement. The leaf incision was simple and linear to lanceolate was the leaf shape. Its leaf margin was covered with hairs and it was dentate. The leaf apex was acuminate and the leaf base was cuneate. Leaf surface was pubescent and its venation was parallel. The ligule morphology was membranous. Its leaf auricle configuration was short and the leaf sheath was split. The leaf measured $25 \mathrm{~cm}$. The inflorescence type of goose grass was observed as raceme. The number of spikes was three to six, with one or two spikes below and the arrangement was whorled that measures $13 \mathrm{~cm}$. For its stem morphology, the shape was flat. The surface of the stem was hairy and the stem modification was rhizomatous. The type of root was fibrous that measured $8 \mathrm{~cm}$.

E. indica is a summer annual grassy weed that germinates in throughout the summer and is adapted to sandy to loam soils and light clays. It is regarded as an invasive species because it can reproduce in large amounts through its
Figure 4. Echinochloa colona. Photo by J.G.L ALLAWAN

rhizomes and seeds. Goose grass is an abundant weed in waste places and along river banks, roads, and settled areas throughout the Philippines (Breeden \& Brosnan, 2009). This species was the second most abundant in the study area. It was also found in the banana plantation in Barangay Lacson, Calinan, Davao City, Barangay New Visayas, Panabo City, Philippines and Barangay Pag-asa, Kapalong, Davao del Norte, Philippines.

\section{Rottboellia cochinchinensis (Maddox et al., 2004)}

Rottboellia cochinchinensis. Figure 6 shows the actual view of $R$. cochinchinensis. This species is commonly known as itch grass. The collected plant measured $45 \mathrm{~cm}$ with alternate leaf arrangement and the leaf incision was simple. The leaf shape was observed as from linear to lanceolate. Its leaf margin was entire, meanwhile its leaf apex was acuminate and the leaf base was cuneate. Leaf surface was hairy and its venation was parallel. For the type of inflorescence, it was observed as raceme with only one spike and the arrangement was compact that measured $10 \mathrm{~cm}$. For its stem morphology, the shape was from round to oval. The surface of the stem was pubescent and the stem modification was tiller. 


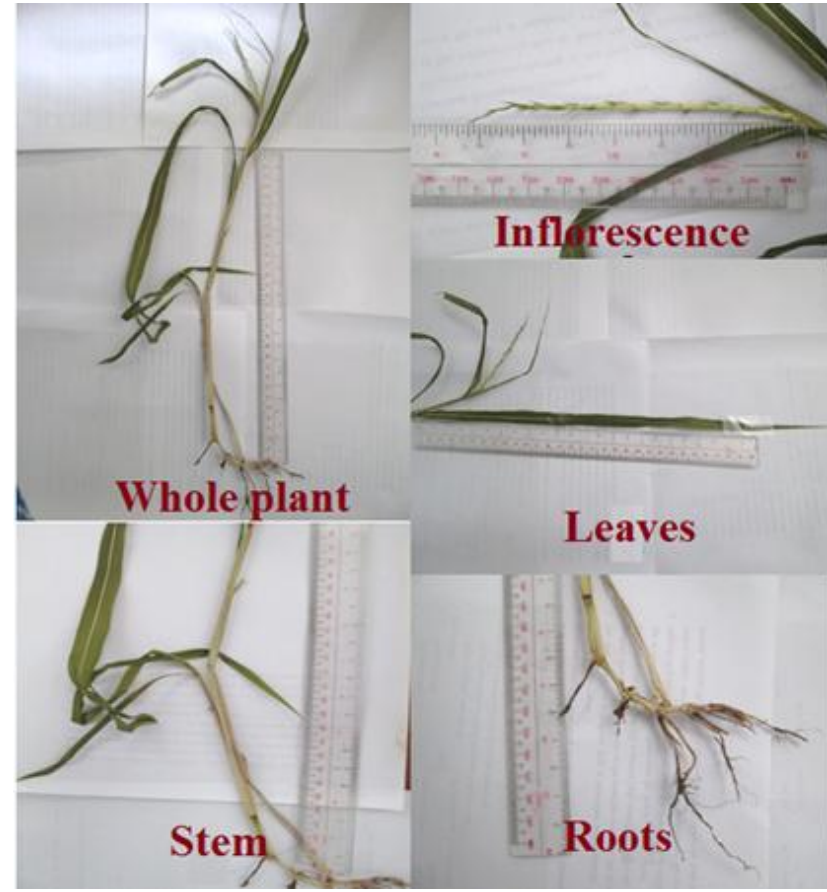

Figure 5. Eleusine indica

Itch grass is an annual grass. It is considered as a weed that can be very competitive in row crops, pastures, and along roadsides. It is a common weed that is widely distributed in the Philippines in moist and waste places (Maddox et al., 2004). R. cochinchinensis was the most abundant grass species in the study area. It was also found as the most abundant grasses in the banana plantation in Barangay Lacson, Calinan, Davao City, Philippines. R. cochinchinensis was also found in Barangay Pag-asa, Kapalong, Davao del Norte. Philippines and New Corella, Davao del Norte. Philippines.

\section{Mimosa pudica (Joseph et al., 2013)}

Mimosa pudica. This legume species belongs to the family Fabaceae and were commonly referred to as the sensitive plant. The plant measured approximately $89 \mathrm{~cm}$ with opposite leaf arrangement. The leaf incision was simple and oblong to lanceolate was the leaf shape. In addition, the leaves were bipinnate and they were also pale green with a tendency of closing when disturbed. Flowers of this plant were observed as axillary and usually occurring in globose heads and its stem was erect, slender, prickly and well-branched. The surface of the stem was hairy.

M. pudica is an annual or biannual sub-woody plant typically spreads in disturbed areas in much of the tropics. It is a common weed that is widely distributed in the Philippines at low and medium altitudes in settled areas (Joseph et al.,

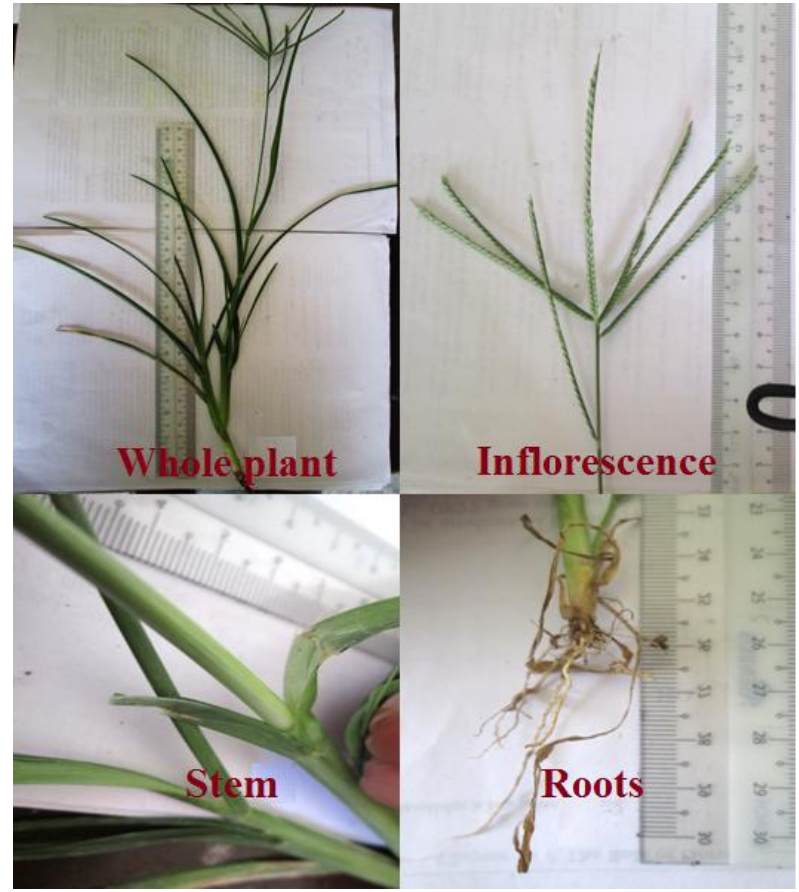

Figure 6. Rottboellia cochinchinensis. Photo by J.G.L ALLAWAN

2013). It is the most abundant legume species in the study area. It was also found as the most abundant legume species in the banana plantation in Barangay Lacson, Calinan, Davao City, Philippines and New Corella, Davao del Norte, Philippines.

\section{Mimosa diplotricha (Sankaran, 2009)}

Mimosa diplotricha. Figure 8 shows the actual view of $M$. diplotricha. It is commonly known as creeping sensitive plant. The plant measured about $88 \mathrm{~cm}$ with alternate leaf arrangement and the leaf incision was simple. The leaf shape was oblong to lanceolate. Its leaf margin was ciliated or glabrous. The leaf apex and leaf base were acute. In addition, each leaf had about 20 pairs of small leaflets. The inflorescence of creeping sensitive plant was observed as globular, and it occurs on short stalks in leaf joints. The pods were linear, flat, and it has small prickles that split transversely into one-seeded sections at the groves. The stem was woody at the decumbent base, with thorns. The roots were profusely branched that has root nodules.

Creeping sensitive plant is an erect shrub and a scrambling climber, which can form dense thickets in a short span of time. It is used as nitrogen fixing cover crop and green manure in several countries in the Asia-Pacific region. The spineless variety is an excellent soil improver and soil binder. It is widely distributed in the Philippines in moist areas (Sankaran, 2009). 


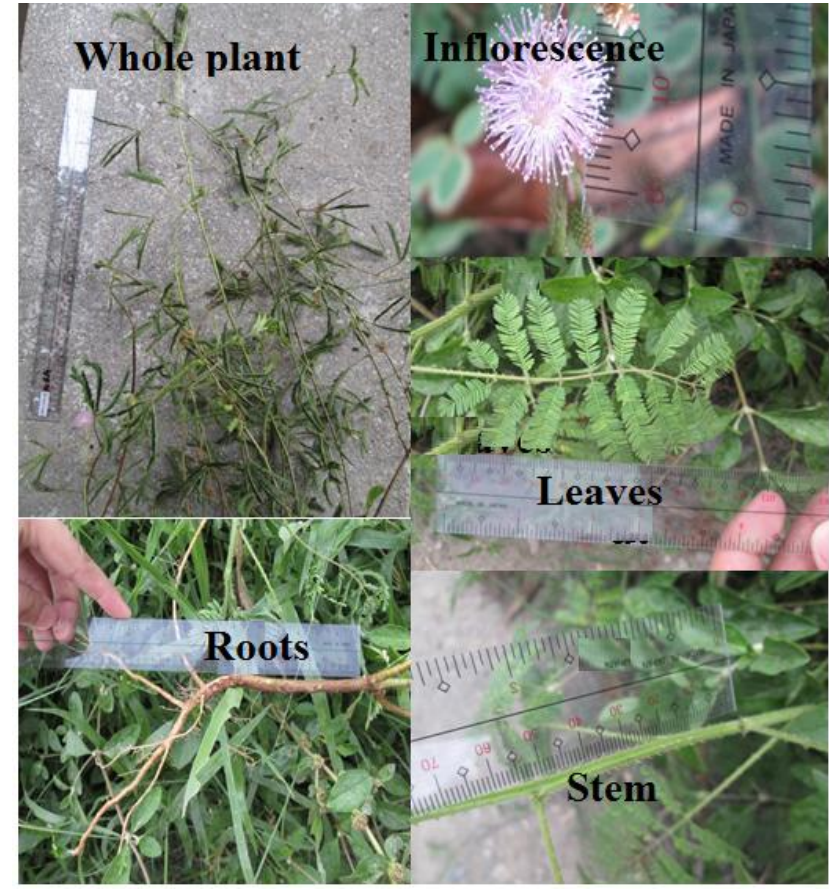

Figure 7. Mimosa pudica

Only a few individuals of $M$. diplotricha were found in the area. It was also in the banana plantation in Barangay Lacson, Calinan, Davao City, Philippines. M. diplotricha was found out that it cannot tolerate shading; otherwise, its growth would be reduced. It was further known to increase fire incidence in some areas (Sankaran, 2009). From these results, it is safe to conclude that this species in the study area is not suitable to become cover crops.

\section{BIODIVERSITY INDICES}

Among the four species identified in this study, $R$. cochinchinensis had the highest frequency value, which was 0.2785 . It occurred in 85 quadrats out of 100. Its relative frequency value was $29.50 \%$. The second most frequent species was $E$. indica which occurred in 80 quadrats, followed by $E$. colona which occurred in 60 quadrats and C. barbata which occurred in the 50 quadrats. Table 1 shows the frequency, relative frequency, density, and relative density of the grass species in the banana field.

Similarly, $R$. cochinchinensis also had the highest density which was 7.8920 and with a relative density of $50.21 \%$. This was followed by E. indica with a density value of 3.1889 and a relative density of $20.29 \%$. C. barbata was the third densest species (2.3927) with a relative density of $15.22 \%$. The least dense species was E. colona with a density value of 2.2449 and a relative density value of $14.28 \%$.

Frequency is the measurement of how frequent a species occurred in an area. Therefore, the high frequency value of $R$. cochinchinensis means that it occurred most frequently. However, frequency values of the other three species were nearly the same. E. indica occurred in 80

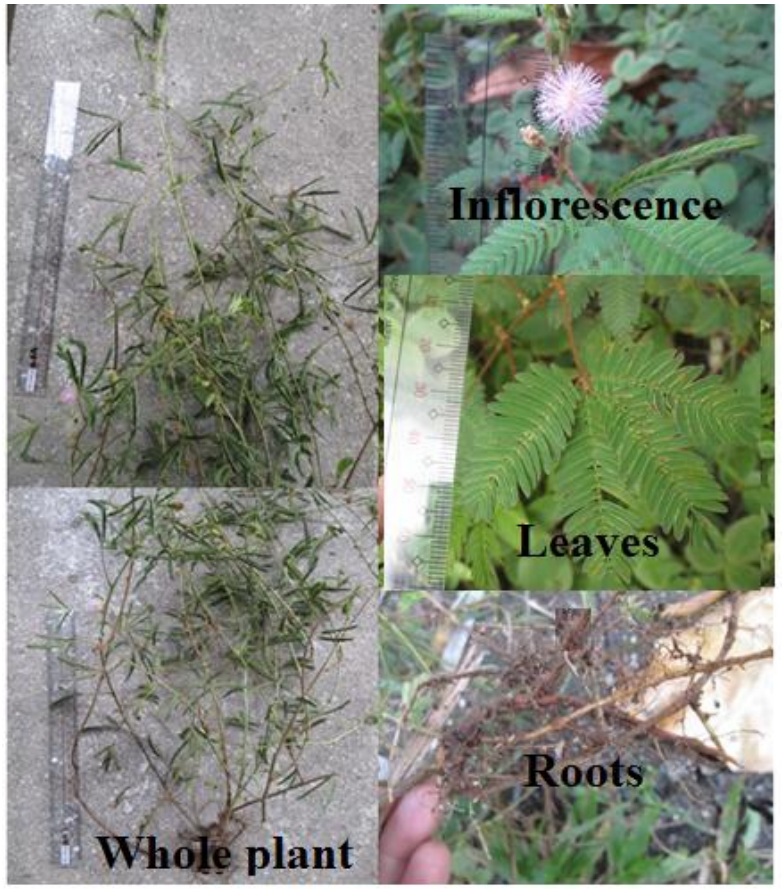

Figure 8. Mimosa diplotricha. Photo by J.G.L ALLAWAN

quadrats with a frequency value of 0.2716 and a relative frequency of $28.77 \%$ while $E$. colona occurred in 60 quadrats with a frequency value of 0.1970 and a relative frequency of $20.87 \%$. C. barbata occurred in 50 quadrats with a frequency of 0.1969. The uneven distribution of grasses in terms of frequency and its density in the banana field could be related to the competency of species to dominate a certain area and the sufficiency of nutrients (Reddy, 2011).

Table 1. Frequency, relative frequency, density, and relative density of grasses

\begin{tabular}{|c|c|c|c|c|}
\hline Grass species & Frequency & $\begin{array}{c}\text { Relative } \\
\text { frequency }\end{array}$ & Density & $\begin{array}{c}\text { Relative } \\
\text { density }\end{array}$ \\
\hline C. barbata & 0.1969 & 20.86 & 2.3927 & 15.22 \\
\hline E. colona & 0.1970 & 20.87 & 2.2449 & 14.28 \\
\hline E. indica & 0.2716 & 28.77 & 3.1889 & 20.29 \\
\hline $\begin{array}{c}R . \\
\text { cochinchinensis }\end{array}$ & 0.2785 & 29.50 & 7.8920 & 50.21 \\
\hline Total & $\mathbf{0 . 9 4 4 0}$ & $\mathbf{1 0 0}$ & $\mathbf{1 5 . 7 1 8 6}$ & $\mathbf{1 0 0}$ \\
\hline
\end{tabular}

M. pudica had the highest frequency, which is 0.1910 . It occurred on 57 out of the 100 quadrats. Its relative frequency value was $52.83 \%$. In contrast, $M$. diplotricha occurred on 53 among the 100 quadrats. Its frequency was 0.1705 and the relative humidity was $47.17 \%$. Table 2 shows the frequency, relative frequency, density and relative density of the legume species. Similarly, M. pudica also had the highest density which was 1.0485 with a relative density of $53.66 \%$. The next dense species was $M$. diplotricha with a density value of 0.9053 and a relative density value of $46.34 \%$. The frequency and density values of these legumes can be related to the fact that it has a broad range of adaptability to diverse soil and climatic conditions (Chalk and Smith, 2017). In addition, the 
uneven distribution of legume species in the area based on the frequency and density values can be related to the competency of species to dominate a certain area and also, the sufficiency of water and nutrients (Fitri et al., 2021).

Table 2. Frequency, relative frequency, species density, and relative density of legumes

\begin{tabular}{|c|c|c|c|c|}
\hline $\begin{array}{c}\text { Legume } \\
\text { species }\end{array}$ & Frequency & $\begin{array}{c}\text { Relative } \\
\text { frequency }\end{array}$ & Density & $\begin{array}{c}\text { Relative } \\
\text { density }\end{array}$ \\
\hline M. pudica & 0.1910 & 52.83 & 1.0485 & 53.66 \\
\hline $\begin{array}{c}M . \\
\text { diplotricha }\end{array}$ & 0.1705 & 47.17 & 0.9053 & 46.34 \\
\hline Total & $\mathbf{0 . 3 6 1 5}$ & $\mathbf{1 0 0}$ & $\mathbf{1 . 9 5 3 9}$ & $\mathbf{1 0 0}$ \\
\hline
\end{tabular}

\section{SPECIES DIVERSITY}

Species diversity was computed using ShannonWiener diversity index which is defined as the summation of natural logarithm of the fraction of the entire population per species encountered multiplied by fraction of the entire population per species. Moreover, effective number of species (ENS) was also computed. ENS is defined as the equally common species in the study area. It is the number of equally common species required to give a particular value of an index (Mashaly et al., 2020).

Table 3 shows the species diversity and effective number of species of the grasses in the study site. The table shows that block 2 had the highest diversity with 1.53 and had effective number of species of 4.61 followed by block 1 with 1.40 and 4.06 , block 3 with 1.39 and 4.03 , and block 4 with 1.35 and 3.85 , respectively. This means that the species proportion in the study area unevenly distributed.

Table 3. Diversity value of grasses and legumes found in the Gillera Farm

\begin{tabular}{|c|c|c|c|c|c|c|}
\hline & Block 1 & $\begin{array}{c}\text { Block } \\
2\end{array}$ & $\begin{array}{c}\text { Block } \\
3\end{array}$ & $\begin{array}{c}\text { Block } \\
4\end{array}$ & Total & Mean \\
\hline $\begin{array}{c}\text { Shannon- } \\
\begin{array}{c}\text { Weiner } \\
\text { Diversity } \\
\text { Index }\end{array}\end{array}$ & 1.40 & 1.53 & 1.39 & 1.35 & $\mathbf{5 . 6 7}$ & $\mathbf{1 . 4 2}$ \\
\hline $\begin{array}{c}\text { Effective } \\
\text { Number of } \\
\text { Species }\end{array}$ & 4.06 & 4.61 & 4.03 & 3.85 & $\mathbf{1 6 . 5 5}$ & $\mathbf{4 . 1 4}$ \\
\hline
\end{tabular}

The value for the Shannon diversity index ranges from 0.0 to 6.0. Values below 1.0 illustrates that the community in the area is disturbed and degrading (Mashaly et al., 2020). Correspondingly, the low species diversity in the area can be expected to be affected by the nutrients and minerals found in the soil. It was noted that the amount of phosphorus, organic matter, and potassium in the soil was very low. Plants obtain nutrients from two natural sources: organic matter and minerals. Soil organic matter is the product of on-site biological decomposition. It affects the chemical and physical properties of the soil. Its composition and breakdown rate affect the: soil structure and porosity; the water infiltration rate and moisture holding capacity of soils; the diversity and biological activity of soil organisms; and plant nutrient availability. Phosphorus and potassium are two of the most important nutrients needed by plants. They are required for the ideal growth and reproduction of grasses. Effective number of species seems completely natural to say that a community with six equally-common species has a diversity of six species, or a community with S equallycommon species has a diversity of S species (Reddy, 2011).

\section{DISCUSSION}

For grasses, the high frequency value of $R$. cochinchinensis means that it occurred most frequently. However, frequency values of the other three species were nearly the same. E. indica occurred in 80 quadrats with a frequency value of 0.2716 and a relative frequency of $28.77 \%$ while E. colona occurred in 60 quadrats with a frequency value of 0.1970 and a relative frequency of $20.87 \%$. C. barbata occurred in 50 quadrats with a frequency of 0.1969 . The uneven distribution of grasses in terms of frequency and its density in the banana field could be related to the competency of species to dominate a certain area and the sufficiency of nutrients (Reddy, 2011).

In legumes, $M$. pudica had the highest frequency, which is 0.1910 . It occurred on 57 out of the 100 quadrats. Its relative frequency value was $52.83 \%$. In contrast, $M$. diplotricha occurred on 53 among the 100 quadrats. Its frequency was 0.1705 and the relative humidity was $47.17 \%$. The frequency and density values of these legumes can be related to the fact that it has a broad range of adaptability to diverse soil and climatic conditions (Fitri et al., 2021). In addition, the uneven distribution of legume species in the area based on the frequency and density values can be related to the competency of species to dominate a certain area and also, the sufficiency of water and nutrients (Chalk and Smith, 2017).

Low soil temperature can limit the plant's ability to obtain nutrients by limiting root growth. Meanwhile all nutrients are supplied as dissolved ions in the water flow to roots; low soil water content simultaneously reduces the availability of nutrients for plant uptake. Certain conditions, such as high $\mathrm{pH}$ combined with high soil lime $\left(\mathrm{CaCo}_{3}\right)$ can be predicted to limit $\mathrm{Zn}, \mathrm{Fe}, \mathrm{Mn}$, and $\mathrm{Cu}$ availability. In general, determination of soil $\mathrm{pH}$ can aid in the diagnosis of nutrient deficiencies. Soil $\mathrm{pH}$ affects the availability of mineral nutrients. Low $\mathrm{pH}(<5.5)$ may result in deficiencies of $\mathrm{Ca}$, $\mathrm{Mg}, \mathrm{P}$, or Mo and perhaps excesses of Mn, Fe or Al. High $\mathrm{pH}$ (>7.5) may immobilize $\mathrm{Mn}, \mathrm{Zn}, \mathrm{Fe}$ or $\mathrm{Cu}$, making them unavailable to the plant (Mahler, 2005).

\begin{tabular}{|c|c|c|}
\hline Species & Nitrogen Content (\%) & $\begin{array}{c}\text { Moisture Content } \\
(\boldsymbol{\%})\end{array}$ \\
\hline C. barbata & 1.14 & 80.4 \\
\hline E. colona & 1.31 & 79.8 \\
\hline E. indica & 1.36 & 73.6 \\
\hline R. cochinchinensis & 1.69 & 80.0 \\
\hline M. pudica & 3.14 & 81.8 \\
\hline M. diplotricha & 1.36 & 82.6 \\
\hline
\end{tabular}


The main nutrient needed by grasses and legumes is the nitrogen. The rate of nitrogen applications was influenced the growth, quality, and distribution of species. The total nitrogen content for legumes is relatively high because of the presence of root nodules. These root nodules harbor nitrogen fixing bacteria that can enhance the nitrogen levels in the soil (Koenig et al., 2002). Moisture content is the water capacity of plant tissue. Water deficiency brings about low quality and quantity of the yield and final results of plant death. Over irrigation can also cause low use efficiency and low plant resistance to water shortage (Miller, 2010).

There are four criteria to be satisfied in order for a certain plant species to be selected as a potential cover crop. These criteria are: its capacity to control weeds; it does not compete with the water and nitrogen requirement of banana; can allow shading from the banana canopy; and must not be a vector of disease (Tixier et al., 2010). Swollen finger grass requires areas with full sunlight and prefers dry areas making it less suitable to become a cover crop. It is also a host of several insects and it was noted as an alternative host of the grass-seed feeding thrips (Chen, 2004). Thus, this identified grass species in the study area is not suitable to become cover crops because none of this species satisfy the given four criteria. Jungle rice grass can tolerate moderate shading. It was a very competitive grass that can reproduce and compete effectively due to its prostate habit (Monsanto, 2012). This grass species is not suitable to become cover crops because none of this species satisfy the given four criteria. Goose grass requires full sunlight exposure for it to grow rapidly. Moreover, it was reported to have wide host range, including bacteria, fungi, nematodes, and insects that attack agricultural plants (Breeden \& Brosnan, 2009). Therefore, this identified grass species is not suitable to become cover crops. Itch grass can tolerate shading and does not compete with the nitrogen and water. However, it was proven that it is a vigorous pest in plantations and it serves as a natural host of several viruses that may be harmful to banana (Maddox et al., 2004). Therefore, this grass species is not suitable to become cover crops.

Sensitive plant was found that it cannot tolerate shading; otherwise, its growth would be reduced. It was also found that this species is a vector of plant nematodes Meloidogyne sp. and Pratylenchus sp. (Joseph et al., 2013). Thus, this legume species is not suitable to become cover crops. M. diplotricha was found out that it cannot tolerate shading; otherwise, its growth would be reduced. It was further known to increase fire incidence in some areas (Sankaran, 2009). From these results, it is safe to conclude that this species in the study area is not suitable to become cover crops.

\section{CONCLUSION}

Based on the findings, there were four identified grass species were found namely: Chloris barbata (swollen finger grass); Echinochloa colona (jungle rice grass);
Eleusine indica (goose grass); and Rottboellia cochinchinensis (itch grass). For legumes, two species were found namely: Mimosa pudica (sensitive plant) and Mimosa diplotricha (creeping sensitive plant).

Also, $R$. cochinchinensis was the most abundant grass in the area, while E. colona was the least abundant. For legumes, M. pudica was the most abundant and M. diplotricha was the least.

Furthermore, the species diversity was obtained by using Shannon-Weiner Diversity Index. Grasses have high species diversity with the value of 1.2411. Legumes on the other hand, had obtained a low value of species diversity which is 0.6905 .

Overall, the author concluded that the grasses and legumes identified in the study area cannot be considered as a potential cover crop. This was based on the results on the nitrogen and moisture contents, in which it shows that it has the capability of competing to the nutrient requirement of banana. The assessment was also based on the four criteria given for it to satisfy as a cover crop.

\section{RECOMMENDATIONS}

Based on the results and conclusions mentioned, the following recommendations are hereby suggested:

Since the result showed a low frequency when it comes to Chloris barbata among the grass species and Mimosa diplotricha among legume species, have a more study to any area or location that is why these species thriving less in the banana plantation.

Banana growers may be suggested for using of research about other plant species thriving in the banana plantation. Thus, this study may serve a guide to them in the field.

Further study on grasses and legumes at the banana field would cover other plant species that are not included in this study. Moreover, to conduct another study in other organisms in the banana field such as other invertebrate and vertebrate animals. Lastly, it is recommended that another study area or environment will be use as the location of the study.

\section{REFERENCES}

[1] Arora, R.K. (2014). Diversity in Underutilized Plant Species - An AsiaPacific Perspective. Bioversity International, New Delhi, India. 1-234. ISBN No.: 978-92-9255-007-3 Retrieved from https://www.bioversityinternational.org/fileadmin/user_upload/ online_library/publications/pdfs/Diversity_in_Underutilized_Plant _Species_An_Asia-Pacific_Prespective_1938.pdf

[2] Breeden, G. \& Brosnan J. (2009). Goosegrass (Eleusine indica). Turfgrass Science Extension, 170, 1-5. Retrieved from https://www.proquest.com/newspapers/dirtynails/docview $/ 853028474 / \mathrm{se}-2$ ?accountid $=31259$

[3] Cartmill, C. (2021). The portview banana project is already ripe for development: Frankly bananas? A banana field and living museum is set to bear fruit for local tourism in east belfast Tourism. News Letter, 33. Retrieved from 
https://www.proquest.com/newspapers/portview-banana-projectis-already-ripe/docview/2529678772/se-2?accountid=31259

[4] Chalk, P. M., \& Smith, C. J. (2017). Nitrogen methodologies for estimating the transfer of $\mathrm{N}$ from legumes to non-legumes in crop sequences. Nutrient Cycling in Agroecosystems, 107(3), 279-301. doi:http://dx.doi.org/10.1007/s10705-017-9842-1. Retrieved from https://www.proquest.com/docview/1892381533/8501C10123694 $564 \mathrm{PQ} / 1$ ? accountid=31259

[5] Chen, C. H. (2004). Germination of Chloris barbata, Cynodon dactylon, and Cyperus rotundus from Angola at constant and alternate temperatures. Agronomy, 9(10), 615. doi:http://dx.doi.org/10.3390/agronomy9100615. Retrieved from https://

www.proquest.com/docview/2545587633/19C0EF2E7DE04521P $\mathrm{Q} / 1$ ?accountid $=31259$

[6] Entsminger, E. D. (2014). Plant community response to reduced mowing regimens along highway right-of-ways in Northeastern Mississippi. Mississippi State University. ProQuest Dissertations Publishing, 1529500094. 1-215. UMI Number: 1554925 Retrieved from https://www.proquest.com/dissertations-theses/plantcommunity-response-reduced-mowing-

regimens/docview/1529500094/se-2?accountid=31259

[7] Fitri, L., Aminah, S. N., Abdullah, T., Widarawati, R., \& Annisa, N. W. (2021). Insect pest in rice field with legumes embankment applied by Beauveria bassiana vuill. IOP Conference Series.Earth and Environmental Science, 807(2) doi:http://dx.doi.org/10.1088/1755-1315/807/2/022108. Retrieved from https://www.proquest.com/docview/2553323803/ $8501 \mathrm{C} 10123694564 \mathrm{PQ} / 28$ ?accountid=31259

[8] Google Earth (October 6, 2014). "Banana field in Gillera Farm, Barangay Kauswagan, Panabo City, Davao del Norte". Date accessed: October 6, 2014

[9] Henning, J., Lacefield, G., Johnson, K., \& Ditsch, D. (2010). Forage identification and use guide. Kentucky Forage and Grassland Council, the University of Kentucky College of Agriculture, 175(1), 1-4. Retrieved from https://www.uky.edu/Ag/ AnimalSciences/pubs/forageidentificationintro.pdf

[10] Jarchow, M. E., \& Liebman, M. (2013). Nitrogen fertilization increases diversity and productivity of prairie communities used for bioenergy. Global Change Biology, Bioenergy, 5(3), 281-289. doi:http://dx.doi.org/10.1111/j.1757-1707.2012.01186.x.

Retrieved

from https://www.proquest.com/docview/2299178914/BEA082FFAC38 4833PQ/5 ? accountid $=31259$

[11] Joseph, B., George, J., \& Mohan, J. (2013). Pharmacology and traditional uses of Mimosa pudica. International Journal of Pharmaceutical Sciences and Drug Research, 5(2), 41-44. Retrieved from http://www.ijpsdr.com/pdf/vol5-issue2/1.pdf

[12] Maddox, V., Westbrooks, R., \& Byrd, J. (2004). Itchgrass (Rottboellia cochinchinensis). Mississippi State University, Geosystems Research Institute, 9, 1-2. Retrieved from http://www.gri.msstate.edu/publications/docs/2009/10/6561itchgra ss_IPAM S.pdf

[13] Mashaly, A., Ahmed, M., \& Ebaid, H. (2020). Relative plant frequency and species richness. Journal of Medical Botany, 57(4), 1006-1011. doi:http://dx.doi.org/10.1093/jme/tjaa041

[14] Miller, E. (2010). Fuel moisture differences in a mixed native and non-native grassland: Implications for fire regimes. Fire Ecology,
12(1), 73-87. doi:http://dx.doi.org/10.4996/fireecology.1201073. Retrieved

from

https://www.proquest.com/docview/2409019951/6C9037CB55F8 48F7PQ/1?accountid=31259

[15] Moines, D. (2018). Webinar covers incorporating cover crops into farm leases: Iowa learning farms monthly webinar will explore best practices for adding cover crops to farm leases. (2018). Des Moines Register. Retrieved from https://www.proquest.com/newspapers/webinar-coversincorporating-cover-crops-into/docview/2036070851/se2 ? accountid $=31259$

[16] Monsanto, C. (2012). Allelopathic activity of crop residue incorporation alone or mixed against rice and its associated grass weed jungle rice (Echinochloa colona [L.] link). Chilean Journal of Agricultural Research, 71(3), 418-423. Retrieved from https://www.proquest.com/scholarly-journals/allelopathic-activitycrop-residue-incorporation/docview/1268174069/se-

2? accountid $=31259$

[17] Moog, F. (2016). Country pasture/forage resource profiles. Food and Agriculture Organization of the United Nations (FAO). 1-23. Retrieved from https://silo.tips/download/country-pasture-forageresource-profiles-philippines-by-francisco-a-moog

[18] Pototan, B. L., Capin, N. C., Tinoy, M. R. M., \& Novero, A. U. (2017). Diversity of mangrove species in three municipalities of Davao del Norte, Philippines. Aquaculture, Aquarium, Conservation \& Legislation, 10(6), 1569-1580. Retrieved from https://www.proquest.com/scholarly-journals/diversity-mangrovespecies-three-municipalities/docview/2056433355/se2? accountid $=31259$

[19] Reddy, G. (2011). Survey of invasive plants on Guam and identification of the 20 most widespread. Micronesica, 41(2), 263274. Retrieved from http://www.wptrc.org/ userfiles/file/reddy/reddy_pp_263-274.pdf

[20] Sankaran, K. V. (2009). Mimosa diplotricha (Giant sensitive plant). Asia - Pacific Forest Invasive Species Network, 2, 1-3. Retrieved from http://www.fao.org/ forestry/133770977cb34791475aa6a7a360640f09778.pdf

[21] Tixier, P., Alvarez, S., Blanchard, M., Ripoche, A., \& Achard, R. (2010). Cover cropping alters the diet of arthropods in a banana plantation: A metabarcoding approach. PLoS One, 9(4) doi:http://dx.doi.org/10.1371/journal.pone.0093740. Retrieved from https:// www.proquest.com/docview/1512317474/5A183CF228AF4EA7P $\mathrm{Q} / 1$ ? accountid=31259

[22] Ussery, H. (2011). Grow cover crops for the best garden soil. Mother Earth News, 50-53. Retrieved from https://www.proquest.com/magazines/grow-cover-crops-bestgarden-soil/docview $/ 903285230 / \mathrm{se}-2$ ?accountid $=31259$

[23] Walter, J., Hein, R., Harald, A., Beierkuhnlein, C., Löffler, S., Reifenrath, K., Schadler, M., Weber, M., \& Jentsch, A. (2012). How do extreme drought and plant community composition affect host plant metabolites and herbivore performance? ArthropodPlant Interactions, 6(1), 15-25. doi:http://dx.doi.org/10.1007/s11829-011-9157-0. Retrieved from https://www.proquest.com/docview/2402246212/BEA082FFAC38 $4833 \mathrm{PQ} / 14$ ? accountid=31259 